\title{
HISTOMORPHOMETRIC EVALUATION OF THE HEALING PROCESS OF BONY DEFECTS FILLED WITH MILLED TEETH VERSUS BETA TRI-CALCIUM PHOSPHATE BONE GRAFT MATERIALS IN RATS
}

\author{
Ghada Mohamed Nasr Hassan $^{1}$, Laila Sadek Ghali ${ }^{2}$, Heba Abdullfattah Elsaied Ahmed ${ }^{3}$
}

DOI: $10.21608 / d s u .2020 .13793 .1001$

Manuscript ID: DSU-1906-1001

\section{KEYWORDS}

Beta tricalcium phosphate Bone graft material, Histomorphometry,

Tooth ash.
- E-mail address: ghhassan90@gmail.com

1. Dentist at Zagazig University Hospitals

2. Prof. of Oral Biology, Faculty of Oral and Dental Medicine, Cairo University. Dean of Faculty of Oral and Dental Medicine, Saini University (Kantara)

3. Lecturer of Oral Biology, Faculty of Dentistry, Suez Canal University

\begin{abstract}
Aim: The aim of the study was the evaluation of healing in bony defects comparing milled teeth versus beta tricalcium phosphate $(B$-TCP) as bone graft materials. Materials and methods: Forty-five male albino rats, were divided into three groups each group included 15 rats; one control and two experimental groups. Under general anesthesia, $1.5 \mathrm{~cm}$ incision was created to expose the cranial bone. Then two bone defects (each one with a diameter of 3 millimeter) were created one in each parital sides. In Group I (control group): the two bony defects (30 bony defects) were left to heal without any intervention. While, in Group II \& III the bony defects were completely filled with $(B$ TCP) and milled teeth, respectively. At the $7^{\text {th }}, 15^{\text {th }}$, and 30 days postoperatively five rates were randomly selected from each group to be sacrificed. Results: histomorophometric and histological results showed a higher level of bone regeneration in the two experimental groups than that of the control group all over the study period, moreover there was a significant increase in the amount of (newly formed bone) in the milled teeth than in the $(B-\mathrm{TCP})$ group. The remaining particles of the two graft materials was significantly less in the milled teeth group than in the $(B-\mathrm{TCP})$ group during the whole study time. Conclusion: Bone activity, formation and maturity were ahead in tooth ash filled calvarial bony defects.
\end{abstract}

\section{INTRODUCTION}

Causes of bone defects include trauma, tumors, and hereditary defects. These bone defects may affect quality of life for the patient. A variety of bone substitutes have been described in the literature aiming to improve the healing in these circumstances. These bone substitutes include autologous bone, allogeneic bone, xenograft, or alloplastic materials ${ }^{(1)}$. These alloplastic materials include, calcium phosphates such as hydroxyapatite (HA) and tricalcium phosphate (TCP) which have a good biocompatibility and a great capacity for osteoconduction as a result of the similarity between its minerals and that of human bone ${ }^{(2)}$

Tooth composition includes inorganic components "calcium phosphate" and organic components such as collagen. Calcium phosphates include the following: hydroxyapatite, only abbreviation should be used in the rest of manuscript (TCP), amorphous-calcium-phosphate 
(ACP), octa-calcium phosphate (OCP), and di-calcium phosphate dehydrate. These inorganic components have a remodeling power on newly formed bone ${ }^{(3,4)}$.

Although tooth was found to be a bone graft material, yet according to our knowledge there is a shortage in studies that evaluate its histomorophometric and histological effect on bone healing ${ }^{(5,6)}$.

\section{MATERIALS AND METHODS}

Preparation of milled teeth bone graft material:

Sound teeth extracted for orthodontic reason (premolar or 3rd molar teeth) were kept in normal saline and prepared as follows:

1. Teeth were cleansed by blade no.15 to remove all attached soft tissues.

2. They were heated in a furnace at $950^{\circ} \mathrm{c}(1742 \mathrm{~F})$ for $30 \mathrm{~min}$ for proteins denaturation.

3. The teeth material was pulverized by means of freezing mechanical grinder. SPEX sample prep 6870 freezer miller machine (Metuchen, USA) was used. This mill cool samples to $-195.8^{\circ} \mathrm{c}$ $(-320.4 \mathrm{~F})$ using liquid nitrogen then grind them by a steel impactor with a magnetically driven back and forth movements. Preparation of milled teeth bone graft material was carried out in Oral and Maxillofacial department, Dental Collage, King Saud University, Saudi Arabia.

This study was conducted after approval of ethical committee no. 2/2017, Faculty of dentistry, Suez Canal University, animal care and handling was in accordance Helsinki declaration for animal use. Forty-five rats (albino, adult, males), weighting 150-200 grams were recruited in the present study. Animals were kept in labeled cages at room temperature with free access to food and water. The animals were kept in the animal house of the faculty of Dentistry, Suez Canal University.

All surgeries were accomplished under aseptic conditions and general anesthesia using intramuscularly injected (ketamine) with a dose of $(35 \mathrm{mg} / \mathrm{kg})$ (Sandoz) and (xylazine) with a dose of $(5 \mathrm{mg} / \mathrm{kg}$ ) (Bimeda). The surgical area was shaved and then disinfected using 10\% Povidone Iodine solution. (Betadine, Purdue Pharma, Norwalk, CT)

Surgical site was injected with about $0.9 \mathrm{ml}$ of local anesthetic (lidocaine 2\%, Parhawk- Laboratories, USA), then one and half centimeter length incision was done using number 15 blade. Then periosteum was sharply incised and elevated ${ }^{(7)}$ Then two noncritical size bone defects ( $3 \mathrm{~mm}$ diameter) were created using dental trephine with a dental drill (Knochenfrasen- Trephine Bur, Germany), bilaterally in parietal bones as shown in (Figure 1).

Animal were classified into three groups: Group I (control group): Consisted of 15 rats, bilateral calvarial bony defects ( 30 bony defects) were left to heal spontaneously. Group II: Consisted of 15 rats, bilateral calvarial bony defects (30 bony defects) were filled with beta tricalcium phosphate bone graft material ( $\beta$-TCP) (Kasios ${ }^{\circledR}$ TCF; Lau-152 naguet, France; Ref: 59.35.0100, Lot: 2182182, with a particle size of 1000-2000 $\mu \mathrm{m})$. Group III: Consisted of 15 rats, bilateral calvarial bony defects (30 bony defects) were filled with Milled Teeth (tooth ash) as shown in (Figure 1).

In all groups, 4-0 vicryl (Ethicon US) was used to close the periosteum, and then 4-0 black silk (Ethicon US) was used to suture the skin. All rats have been injected intramuscularly with Amikacin with a dose of (5mg/lb. bid) (EPICO), then, amoxicillin 10mg/lb. bid (Misr Co. for Pharmaceutical Industries), po (orally) for five-days, Meloxicam 


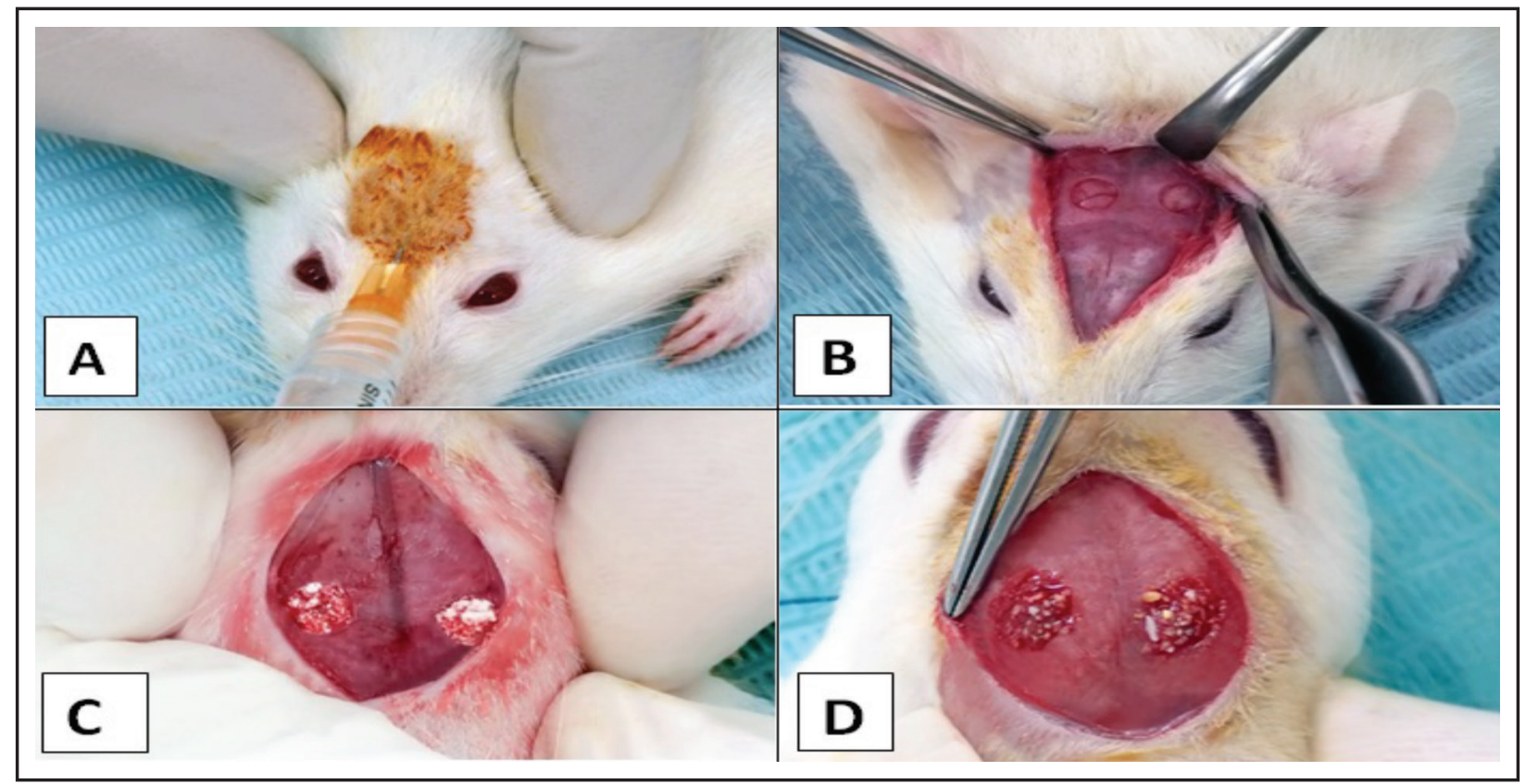

Fig. (1) A photograph showing the surgical field disinfected, and injected with local anesthetic solution. Group I (B), bilateral calvarial bony defects prepared in the parietal bone area and were left to heal spontaneously. Group II (C) completely filled with beta tricalctum phosphate bone graft material (B-TCP). Group III (D) completely filled with Milled Teeth (tooth ash).

$(0.5 \mathrm{mg} / \mathrm{kg}$, p.o.) ( Boehringer Ingelheim) was given for three days for inflammation and pain control. Five rats were randomly selected from each group to be sacrificed in 3 postoperative evaluation intervals $(7,15$, and 30 postoperative-days).

Specimens have been fixed in 10\% formalin (Fisherbrand), then decalcified in $10 \%$ EDTA solution (Ricca Chemicals) and processed according to a standardized protocol for staining by Haematoxylin and eosin (H\&E) and Masson's trichrome staining ${ }^{(5)}$.

\section{Histomorophometric analysis}

The stained sections were evaluated by optical microscope. The amounts of newly formed bone were measured using computer-assisted histomorphometry. Bone healing histomorphometry was carried out semi-automatically on (H\&E) and Masson's trichrome sections, and a number of 20 images were studied with a X4 objective using a microscope with $1 / 2$ photo adaptor, with a digital camera (Olympus) connected to a computer using Image J $1.37 \mathrm{v}$ (National Institutes of Health, Bethesda, MD; http:// rsb.info.nih.gov/ij/). Using a scale with 300 pixels equal to $1 \mathrm{~mm} 2$ and a separate surface area was bordered using the polygon selection tool for measurement. Sections were analyzed using Fiji Image J processing package software (https://fiji.sc/). The static parameters of bone formation were calculated as a percentage.

\section{STATISTICAL ANALYSIS}

Using unpaired samples (t-test) to statistically analyze the data collected from the histomorophometric analysis considering the results significant when $\mathrm{p} \leq 0.05$. 
The variables that were evaluated are the total tissue area which include (granulation tissue, new bone formation, and the amount of remaining grafted particles) (in $\beta$-TCP group and tooth ash group).

\section{Histological results}

Examining the Sections stained with Haematoxylin \& Eosin stain revealed that; In the control group (Group I); healing of the calvarial bony defects proceeded in a normal sequence of bone healing starting at day 7 and increased up to day 30 . At day 7 bone defects were found to be filled with granulation tissue which was replaced by bony trabeculae radiating from the periphery towards the center of the bone defect. These bony trabeculation appeared at day 15 , and increased at day 30 postsurgically as shown in (Figure 2).

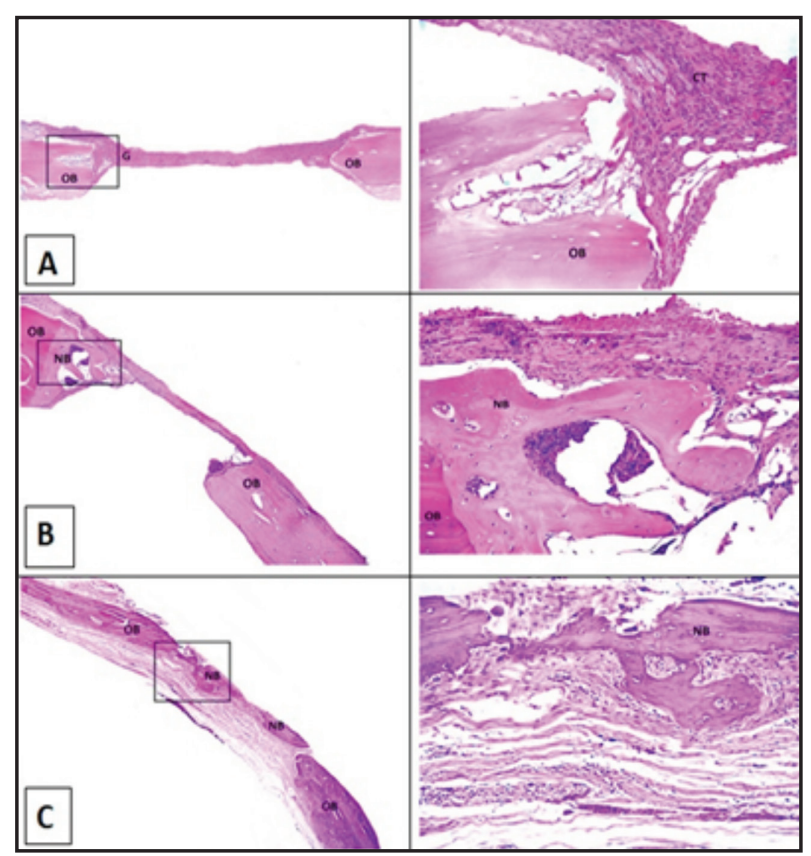

Fig. (2) Photomicrograph of Group I at day 7(A), Day 15 (B), Day 30 (C) postsurgically showing edges of old bone $(\mathrm{OB})$, granulation tissue $(\mathrm{G})$, fibrocellular connective tissue $(\mathrm{CT})$, and newly formed bone trabeculae (NB). (H\&E x 40) (H\&E x 200)
In experimental group II; healing of calvarial bony defects started at day 7 was faster in comparison to control group, as revealed by the increased number and thickness of bony trabeculae from day 15 to day 30 also reduced size of bone marrow spaces at day 15 and the prominent appearance of their coalescence at day 30 postsurgical as shown in (Figure 3).

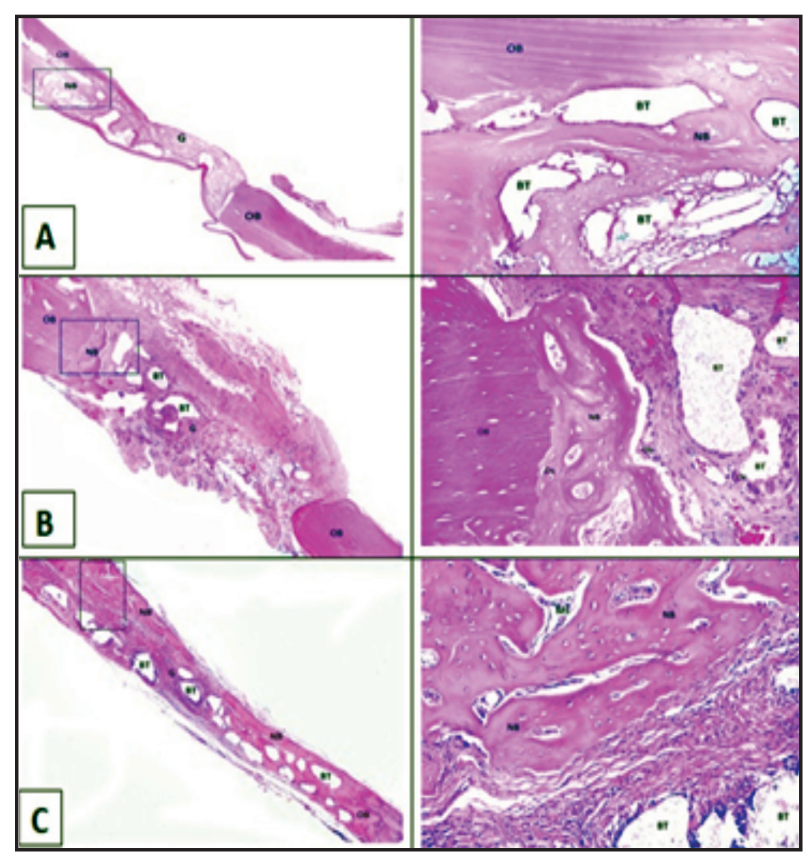

Fig. (3) Photomicrograph of Group II at day 7(A), Day 15 (B), Day 30 (C) postsurgically showing edges of old bone $(\mathrm{OB})$, granulation tissue $(\mathrm{G})$, newly formed bone trabeculae $(\mathrm{NB})$, betatricalcium phosphate $(\mathrm{BT})$, osteoclast cells (OC), osteoblasts (OB), AND osteocytes (OS). (H\&E x 40) (H\&E x 200)

In experimental group III; the newly formed bone trabeculae appeared at day 7 and, increased in number \& thickness from day 15 to day 30 postsurgically. Increased maturity of bone trabeculae at day 30 and narrowing of calvarial bony defect. The activity and maturity of the bone defect was ahead in experimental group III as compared to the other groups as shown in (Figure 4). 


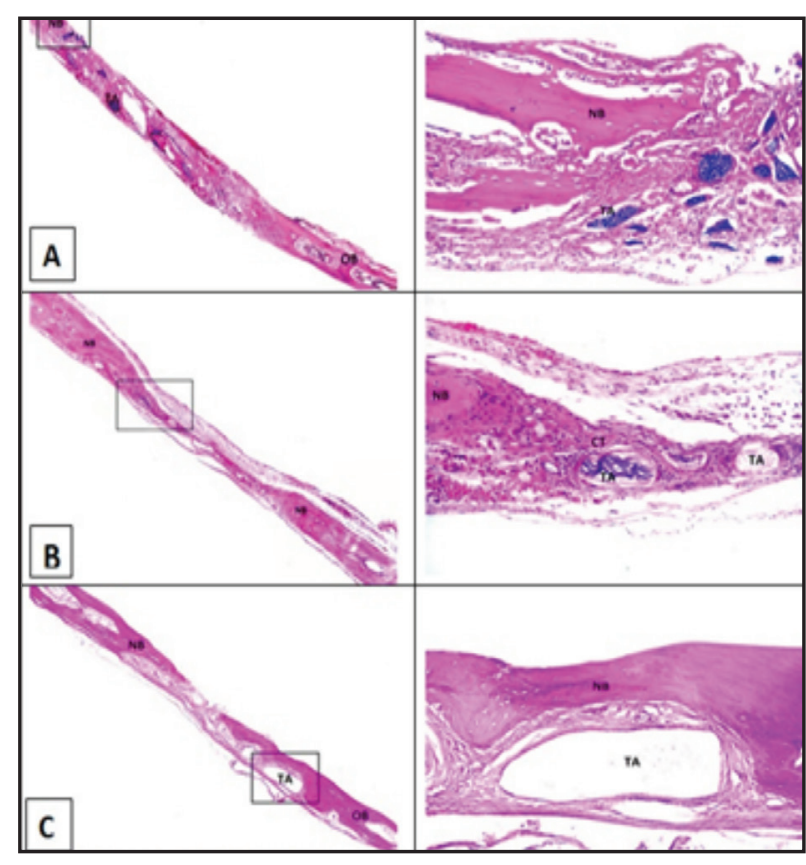

Fig. (4) Photomicrograph of Group III at day 7(A), Day 15 (B), Day 30 (C) postsurgically showing edges of old bone (OB), fibrocellular connective tissue (CT), and newly formed bone trabeculae (NB), Tooth ash (TA) (H\&E x 40) (H\&E x 200)

\section{Histomorphometric and Statistical Analysis}

The Histomorphometric and statistical analysis revealed the following results:

The new formation of bone in the two study groups was more than that of the control group all over the study period, moreover results revealed a significant increase in the amount of new bone formation in the tooth ash group than the $(\beta$-TCP group) at $7,15,30$ days' post surgically with a $p$ value $0.003,0.001,0.0001$ respectively (Table 1 ).

This elevation in the amount of new bone formation came on at the expense of granulation tissue formed in the study area. The histomorphometric analysis showed that the granulation tissue showed its maximum amount in the control group, and a significant difference in its amount was seen between the two study groups. As the tooth ash group showed fewer amounts of granulation tissues than the ( $\beta$-TCP) graftat 15,30 days' post surgically with a $p$ value, 0.0001 , and 0.045 respectively. While the amount of these granulation tissues was more in the tooth ash graft than the $\beta$-TCP group only at the 7 -day post surgically $p 0.0005$ and this was shown on the expenses of remaining particles of the tooth ash material (table 2).

Table 1: Illustrates the statistical analysis results of the amount of new bone formation in the two experimental groups at 7, 15, 30 days post-surgically using unpaired samples $t$-test.

\begin{tabular}{|c|c|c|c|l|}
\hline \multirow{7}{*}{} & \multicolumn{3}{|c|}{ NEWLY FORMED BONE } & \multirow{2}{*}{ P value } \\
\cline { 2 - 4 } & $\begin{array}{c}\text { Control Group } \\
\text { Mean } \pm \text { SD }\end{array}$ & $\begin{array}{c}\text { BTCP Group } \\
\text { Mean } \pm \text { SD }\end{array}$ & $\begin{array}{c}\text { TA group } \\
\text { Mean } \pm \text { SD }\end{array}$ & \\
\hline 7 days & $\begin{array}{c}0.2174 \\
\pm 0.0766\end{array}$ & $\begin{array}{c}0.9112 \pm \\
0.0388\end{array}$ & $\begin{array}{c}1.1090 \\
\pm 0.1194\end{array}$ & $0.003^{*}$ \\
\hline \multirow{2}{*}{15 days } & $\begin{array}{c}0.5528 \\
\pm 0.1118\end{array}$ & $\begin{array}{c}1.5702 \\
\pm 0.2178\end{array}$ & $\begin{array}{c}2.0018 \pm \\
0.0765\end{array}$ & $0.001^{*}$ \\
\hline 30 days & $\begin{array}{c}1.8172 \\
\pm 0.1615\end{array}$ & $\begin{array}{c}2.851 \\
\pm 0.0773\end{array}$ & $\begin{array}{c}3.3266 \pm \\
0.1490\end{array}$ & $0.0001^{*}$ \\
\hline
\end{tabular}

*Significant difference $p<0.05$.

Table 2: Illustrates the statistical analysis results of the amount of granulation tissue formation in the two experimental groups at 7, 15, 30 days postsurgically using unpaired samples t-test.

\begin{tabular}{|c|c|c|c|c|}
\hline \multirow{7}{*}{} & \multicolumn{3}{|c|}{ GRANULATION TISSUES } & \multirow{2}{*}{$P$ value } \\
\cline { 2 - 4 } & $\begin{array}{c}\text { Control Group } \\
\text { Mean } \pm \text { SD }\end{array}$ & $\begin{array}{c}\text { BTCP Group } \\
\text { Mean } \pm \text { SD }\end{array}$ & $\begin{array}{c}\text { TA group } \\
\text { Mean } \pm \text { SD }\end{array}$ & \\
\hline \multirow{2}{*}{7 days } & $\begin{array}{c}6.9416 \\
\pm 0.1147\end{array}$ & $\begin{array}{c}3.7344 \\
\pm 0.1754\end{array}$ & $\begin{array}{c}4.2508 \\
\pm 0.1526\end{array}$ & $0.0005^{*}$ \\
\hline \multirow{2}{*}{15 days } & $\begin{array}{c}6.4996 \\
\pm 0.1194\end{array}$ & $\begin{array}{c}4.0174 \\
\pm 0.0718\end{array}$ & $\begin{array}{c}3.4238 \\
\pm 0.1959\end{array}$ & $0.0001^{*}$ \\
\hline \multirow{2}{*}{30 days } & $\begin{array}{c}5.8958 \\
\pm 0.0944\end{array}$ & $\begin{array}{c}3.235 \\
\pm 0.1866\end{array}$ & $\begin{array}{c}3.0434 \\
\pm 0.1225\end{array}$ & $0.045^{*}$ \\
\hline
\end{tabular}

*Significant difference $p<0.05$. 
The histomorphometric evaluation of the remaining particles of the two graft materials showed significantly less particles in the tooth ash group than in the $\beta$-TCP group all over the study period 7 , 15,30 days postoperatively with a $p$ value of 0.021 , $0.007,0.004$ respectively (Table 3 ).

Table 3: Illustrates the statistical analysis results of the amount of bone graft particles in the two experimental groups at 7, 15,30 days post-surgically using unpaired samples $t$-test.

\begin{tabular}{|c|c|c|l|}
\hline \multirow{2}{*}{} & \multicolumn{2}{|c|}{ REMAINING PARTICLES } & \multirow{2}{*}{ P value } \\
\cline { 2 - 3 } & $\begin{array}{c}\text { BTCP Group } \\
\text { Mean } \pm \text { SD }\end{array}$ & $\begin{array}{c}\text { TA group } \\
\text { Mean } \pm \text { SD }\end{array}$ & \\
\hline 7 days & $2.6054 \pm 0.2297$ & $2.2836 \pm 0.1904$ & $0.021^{*}$ \\
\hline 15 days & $2.1872 \pm 0.2231$ & $1.8294 \pm 0.1373$ & $0.007 *$ \\
\hline 30 days & $1.532 \pm 0.1572$ & $1.2100 \pm 0.1409$ & $0.004 *$ \\
\hline
\end{tabular}

*Significant difference $p<0.05$.

\section{DISCUSSION}

Bone regeneration using bone graft materials became a common procedure ${ }^{(8)}$.The best materials for bone regeneration are autogenous bone. Still, the main limitation of the use of autogenous bone grafts is the restricted amounts and donor site morbidity. Therefore, bone grafts includig allogenic, xenogeneic, and alloplastic materials have been developed. $\beta$-TCP has been widely used with the advantage of its biodegradability, harmlessness, and relatively low $\operatorname{cost}^{(8)}$

Recently; researchers choose autogenous tooth bone graft (Auto BT) which allows both formations of new bone and is steadily observed to be replaced by bone without compromising on the bone-regeneration capacity ${ }^{(9)}$ Teeth contain stem cells, trace metal ions, and growth factors ${ }^{(10)}$. Although there is a difference between bone and dentin regarding structure, the ratio of the organic and inorganic contents is nearly similar. Dentin also contains some growth factors as, insulin-like growth factor-II, bone-morphogenetic protein (BMP), and transforming growth factor ${ }^{(11)}$. Furthermore, Dentin contains proteins that are similar to bone, including, osteopontin, bone sialoproteins, dentin sialoproteins, osterix, and osteocalcin due to which it was considered as an effective alternative bone grafting material $^{(12)}$.

Regarding newly formed bone the present study found that both $\beta$-TCP and tooth ash groups showed increased newly formed bone than the control group. The advantage of ( $\beta$-TCP) group over the control group in intensifying the amount of bone formation showed in the study results agrees with the study held by Komaki et al., ${ }^{(13)}$ Iskaros et al ${ }^{(14)}$ as they explained its dominant effect on stimulating new bone formation to the importance of its macroporosity structure.

Yet, comparison between the results of new bone formation in ( $\beta$-TCP) and Tooth ash groups in the present study; showed a significant increase in the amount of new bone formation all over the study period between the two study groups in favor of the tooth ash group. These findings came in accordance with Kim et al ${ }^{(6,9)}$, de Oliveira et al ${ }^{(15)}$, and Park et $\mathrm{al}^{(16)}$, as they attribute the high affinity of tooth ash in stimulating new bone formation to its composition. The main inorganic component is HA, that has an osteoconductive property, in addition to the osteoinductive effect of the organic component in case of autogenous tooth application ${ }^{(15,6,9,16)}$.

Moreover, the present results again came on line with the findings of $\mathrm{KimYK}^{(17)}$, and Kim JW(18) groups as they mentioned that the composition of 
dentin has a strong influence on bone formation and bone remodeling, and they referred this to the similarity between the type of hydroxyapatite in dentin and that of bone ${ }^{(17,18,19)}$.

Furthermore, Min et al (2) stated that tooth ash includes an amount of $\beta$-TCP in the deciduous tooth ash (DTA) and permanent tooth ash (PTA) equal 10.7 and $3.7 \%$, respectively. And this can explain the superior results of tooth ash over the $\beta$-TCP regarding bone formation in the present study as tooth ash by its composition gathered the advantages of $\beta$-TCP as a part of its composition plus the advantages of the tooth ash itself that comes from its inorganic structure and organic components including growth factors and stem cells ${ }^{(2)}$

In the present study the increase in new bone formation came on at the expense of granulation tissues and remaining graft particles in the study area. The histomorphometric analysis showed that the granulation tissues showed its maximum amount in the control group all over the study period in the region of interest during the histomorphometric evaluation in comparison with the $\beta$-TCP and tooth ash groups. This could be explained by the absence of any graft material in the area examined and the small amounts of newly formed bone which was obviously high in the other two groups. And the elevated amount of the regenerated bone in the bone graft materials groups came on the expense of earlier differentiation and maturation of these inflammatory tissues and these results came on line with Miretta ${ }^{(20)}$ as he stated that Hydroxyapatite coating enhanced significantly granulation tissue formation, maturation, neovascularization estimated by macroscopic observations and histological criteria beside many growth factors ${ }^{(20)}$.

Comparing the amount of granulation tissues formed in the $\beta$-TCP group with the tooth ash group showed substantial difference and sudden transformation during the study period. At 7 days post-surgically tooth ash group showed significantly more granulation tissues than the $(\beta-\mathrm{TCP})$ group while, at the rest of the study period this relation was reversed as the amount of granulation tissues became significantly higher in the $(\beta-\mathrm{TCP})$ group. This could be explained in the first postsurgical week by the rapid resorption rate of the tooth ash group then the $(\beta$-TCP) group which was manifested by the significant difference in the amount of remaining graft particles between the ( $\beta$-TCP) group and tooth ash group all over the study period with its higher difference in the first 7 days post surgically. This means that the increase of the granulation tissue in this period in the tooth ash group came on the expense of the remaining particles. While in the next two scarification periods the resorption rate of the $(\beta$-TCP) particle showed an increase yet the tooth ash still showed a significant rate of resorption but in a lesser rate.

These results come in accordance with Kumar et al (21) and Munoz-Ruiz et al ${ }^{(22)}$ whom reported that $(\beta$-TCP) alone stimulated new bone formation at 4 weeks with the presence of fibrous connective tissue, but with remnants of the ( $\beta$-TCP) particles and inflammatory cells in some areas ${ }^{(21,22)}$.

In the present study both of the two graft materials showed a balance in-between the particles resorption rate and the new formation of bone rate as the statistical results showed a reversible fit between the amount of newly formed bone and the remaining amount of the graft particles and these results put the two materials in the area of ideal requirement of the graft material. Merten group (2003) stated that volume of degradable bone graft material should ideally decrease proportionally as the new bone forms. Fast resorption compromises the space maintaining property and allows soft 
tissues to invade the augmented space. Slower resorption also compromises the process of new bon regeneration ${ }^{(23)}$.

The superior results of the tooth ash material in the present experimental study regarding new bone formation and balanced resorption rate come in agreement with a variety of clinical studies. Kim et al ${ }^{9}$ used demineralized autogenous tooth graft simultaneously with placement of implants and they stated that tooth derived bone substitutes had given a promising results. Lee et al ${ }^{(24)}$ conducted a study to compare the efficiency of autogenous tooth graft and other graft materials used in sinus bone graft surgeries, autogenous tooth graft showed a rapid and better bone quality formation.

\section{CONCLUSION}

1. Bone healing was faster in the calvarial bony defects of the two experimental groups filled with tooth ash and $\beta$-TCP as compared to control ones.

2. Bone activity, formation and maturity were ahead in tooth ash filled calvarial bony defects.

3. The remaining particles of the two graft materials showed higher resorption in the tooth ash groups than in the $\beta$-TCP group

\section{ACKNOWLEDGEMENT}

Authors would like to thank Oral and Maxillofacial department, Collage of Dentistry, King Saud University for their help regarding milling of the teeth

\section{Conflict of interest}

Authors have no conflict of interest to declare

\section{REFERENCES}

1. Meijer G, de Bruijn J, Koole R, van Blitterswijk C. Cell-based bone tissue engineering. PLOS Medicine 2007; 4: 260-264

2. Min B, Song J, Kim O. Osteoconduction capacity of human deciduous and permanent teeth ash in a rat calvarial bone defect model. Cell Tissue Bank 2015; 16:361-369.

3. Bhattacharjya C, Gadicherla S, Kamath A, Smriti K, Pentapati K. Tooth derived bone graft material. World J Dent 2016; 7:32-35.

4. Murata M, Akazawa T, Mitsugi M, Um I. Human dentin as novel biomaterial for bone regeneration. In: Rosario Pignatello R. (ed.) Biomaterials- Physics and Chemistry, InTech; 2011; 127-140.

5. Kim S, Kim Y, Lim S, Kim K, Um I. Histomorphometric analysis of bone graft using autogenous tooth bone graft. Implantology. 2011; 15: 134-141.

6. Kim Y. Bone graft material using teeth. J Korean Assoc Oral Maxillofac Surg. 2012; 38: 134-138.

7. Abdullah W. Evaluation of bone regenerative capacity in rats calaverial bone defect using platelet rich fibrin with and without beta tri calcium phosphate bone graft material. Saudi Dent J 2016; 28: 109-117.

8. Fulin C, Tianqiu M, Kai T, Shujun C, Guicong D, Xiaoming G. Bone graft in the shape of human mandibular condyle reconstruction via seeding marrow-derived osteoblasts into porous coral in a nude mice Model. Scien. Art. J Oral Maxillofac surg 2002;60: 1155-1159.

9. Kim Y, Kim S, Byeon J, Lee H, Um I, Lim S, Kim S. Development of a novel bone grafting material using autogenous teeth. Oral Surg Oral Med Oral Pathol Oral Radiol Endod 2010; 109:496-503.

10. Murata M, Akazawa T, Mitsugi M, Kabir M. Autograft of dentin materials for bone regeneration. In: Pignatello R, editor. Advances in Biomaterials Sciences and Biomedical Applications. Croatia: InTech; Chapter 15. 2013; 391-403.

11. Smith A. Vitality of the dentin-pulp complex in health and disease: Growth factors as key mediators. J Dent Educ 2003; 67:678-689.

12. Sarala C, Chauhan M, Sandhya P, Dharmendra C, Mitra N. Autogenous tooth bone graft: Ingenious bone regeneration material. Indian J Dent Sci 2018; 10:56-59. 
13. Iskaros M, Silver J, Blye J, Cardenas M. Does B-Tricalcium Phosphate Work as a Bone Regenerative Material? J Dent Oral Biol. 2017; 2: 1106-1109.

14. Komaki H, Tanaka T, Chazono M, Kikuchi T. Repair of segmental bone defects in rabbit tibiae using a complex of beta-tricalcium phosphate, type I collagen, and fibroblast growth factor-2. Biomaterials 2006; 27:5118-5126.

15. Park M, Mah Y, Kim D, Kim E, Park E. Demineralized deciduous tooth as a source of bone graft material: its biological and physicochemical characteristics. Oral Surg Oral Med Oral Pathol Oral Radiol 2015; 120:307-314.

16. De Oliveira G, Miziara M, Silva E, Ferreira E, Biulchi A, Alves J. Enhanced bone formation during healing process of tooth sockets filled with demineralized human dentine matrix. Aust Dent J. 2013; 58:326-332.

17. Kim Y, Kim S, Oh J, Jin S, Son J, Kim S. Analysis of the inorganic component of autogenous tooth bone graft material. J Nanosci Nanotechnol. 2011; 11:7442-7445.

18. Kim G, Yeo I, Kim S, Um I, Kim Y. Analysis of crystalline structure of autogenous tooth bone graft material: X-Ray diffraction analysis. J Korean Assoc Oral Maxillofac Surg. 2011; 37:225-228.
19. Murata M, Akazawa T, Hino J, Tazaki J, Ito K, Arisue M. Bioche-mical and histo-morphometrical analyses of bone and cartilage induced by human decalcified dentin matrix and BMP-2. Oral Biol Res 2011; 35:9-14.

20. Miretta T. Granulation Tissue Formation, the effect of hydroxyapatite coating of cellulose on cellular differentiation. Sarja - Ser. D Osa - Tom. Medica - Odontologica. 2010; 909:24-37.

21. Kumar V, Cotran R, Robbins S. Patología Humana. 7th ed. Madrid, Elsevier, 2004.

22. Muñoz-Ruíz A, Silva-Benítez E, Soto-Sainz E, CerdaCristerna B, Ortiz Magdaleno M, Pozosguillen A, Flores $\mathrm{H}$. Evaluation of decellularized matrix and $\mathrm{b}$ tricalcium phosphate as biomaterials for bone neoformation. in vivo study. Int. J. Morphol. 2017; 35:804-811.

23. MertenH,HönigJ,KrantzC,WiltfangJ.Histomorphologische Untersuchungen zum Resorptionsverhalten phasenreiner ß-TCPKeramiken im Tibiadefekt des adulten Minipigs. Osteosynthese Int. J 2000; 8:107-110.

24. Lee J, Kim Y, Su-Gwan K, Lim S. Histomorphometric study of sinus bone graft using various graft material. J Dental Rehabilitation and Applied Science 2011; 27: 141-147. 